\title{
NOTION, TENDENCIES, MILESTONES, PRINCIPLES OF CRIMINALISTICS
}

\author{
Fenyvesi Csaba \\ Faculty of Law \\ University of Pécs \\ 12 Atléta str., Pécs, Hungary, 7623
}

\begin{abstract}
Criminalistics is, in essence, mainly a practical and - to a smaller extent - theoretical science of criminal investigation, in other words, it is a branch of criminal sciences that explores, creates, systemizes and applies - within normative legal frames - means and methods for the detection (prevention) and proving of crime. Apart from the supplementary role of the effective - indirect and direct - prevention of crime, its basic functions comprise detection, obtaining as much and as reliable evidence as possible, providing a basis for and ensuring the ultimate establishment of criminal responsibility by the court. In summary, criminalistics is the science of the effective and professional investigation of crime.

The study shows the criminalistics' continental and common law notion, contacts with other criminal and non criminal disciplines and actual world tendencies and the most important six theoretical principles. The author writes about the historical milestones of the development of criminalistics as a fact science.

All of them would be useful for the specialist, explorer, data collector, the efficient law enforcer, who undertakes risks and dangers, faces continual challenges, the "great fighter" on the real and virtual battlefields that seem unremittingly infinite, where he/she has really only one weapon in his/her hands: criminalistics as an "international treasure".

Keywords: clues, crime investigation, criminalistics, DNA, computarisation, digital data, factscience, forensic sciences, milestones, notion, principles, tendencies, traces.
\end{abstract}

\section{Introduction}

Pursuant to a fragment of a decree issued in 294 by Emperor Diocletian: “.....alud nihil in iudiciis quam iustitiam locum habere debet", which means that the task (aim) of court proceedings is nothing else but to find out the truth. However, in criminal cases it takes a long way to this "finding out". First of all, one has to find the facts that are relevant from the aspect of criminal law as well as the evidence supporting those facts. There is also another saying formulated by Roman law which has been incontestable since then and can be ranged among basic principles: da mihi factum, dabo tibi ius. Give me the fact(s), I will give you the law.

Calling to account in criminal cases or the application of criminal substantive law within the frames of criminal procedure is unimaginable without a factual basis or knowledge of the facts. Questions of fact always precede law, since the law may be applied only based on the knowledge of the facts. On the other hand, the requirement to find the facts leads on to the science of criminalistics.

In the same way as criminal law without procedural law is only a knife handle without the edge, and the other way round, procedural law without criminal substantive law is an edge without a handle, one may also say - based on this pattern - that the law of criminal procedure is only a handle without the edge of criminalistics, and likewise, criminalistics is only an edge without the handle of criminal procedural law [1].

In criminal cases of significance one cannot expect successful and undistorted criminal proceedings or, within their frames, fair and just adjudication without the accurate and authentic exploration of facts.

\section{Aims of research}

In the spirit of earlier thoughts the study:

a) examines the components of the continental and common law conceptions of the discipline, their differences and identical characteristics as well as their tendencies;

b) reviews the historical antecedents of criminalistics; 
c) highlights the main stages in the world history of criminalistics and pinpoints its milestones;

d) defines and analyses the (tendentious) principles of criminalistics;

e) elaborates on the world trends of modern criminalistics.

\section{Main part - Result and discussion}

3. 1. The continental and common-law notion, system and contacts of criminalistics and their tendencies (The notion and purpose of criminalistics)

Academic literature seems to be uniform in its summary, formulated also below, that criminalistics is, in essence, mainly a practical and - to a smaller extent - theoretical science of criminal investigation, in other words, it is a branch of criminal sciences that explores, creates, systemizes and applies - within normative legal frames - means and methods for the detection (prevention) and proving of crime

[2]. Apart from the supplementary role of the effective - indirect and direct - prevention of crime, its basic functions comprise detection, obtaining as much and as reliable evidence as possible, providing a basis for and ensuring the ultimate establishment of criminal responsibility by the court. In summary, criminalistics is the science of the effective and professional investigation of crime, which has no subfield, either on the European continent having given birth to it or beyond the borders of Europe, that does not serve the fight against crime, the detection of offenders and their being brought to trial.

Even the expression "criminalistics" is of the European origin, since it was first used by GROSS in his basic work of 1893, which was translated in the English language publication as the headword "criminal investigation" and it was used in that form right until the 1950s-1960s, and it is still used today, albeit with a changed content.

In the common-law jurisdictions (Great-Britain, USA, Canada, Australia etc) "criminalistics" as a scientific term relating to the whole branch of science has not become widespread, or it is not to be interpreted in its European meaning. Following the initial "criminal investigation" - through the designations "scientific investigation" and "police science" - especially from the 1960s the terminology of "forensic science" - translated into Hungarian as bünügyi tudomány=criminal science (or törvényszéki tudomány= court science, or maybe igazságügyi tudomány= judicial science) - has been used. In my view, there is no need to find a Hungarian translation for this term, since the attribute "forensic= forenzikus" can serve as a solution that may be accepted internationally as well [3].

Therefore, in my opinion, the term "forenzikus tudomány" as the Hungarian expression for the common law terminology (forensic science) is simply a Hungarianized equivalent, its attributive form is adequately expressive and it is becoming more and more accepted.

On the other hand, today, in my view, forensic science as a technical term of American origin based on the common law conception ("forensic science"), as a matter of fact, exhibits the content of continental crime-solving techniques, while the elements of crime-solving tactics can mainly be detected in criminal psychology (or forensic psychology) and "criminal investigation". Consequently, by scientific investigation of crime ("forensic scientific investigation") or detection of crime ("detection"), Anglo-Saxon academic literature means the application of natural scientific methods [4].

Based on the traditional approach, behind "criminalistics" as a technical term there is only one "branch of forensic science", namely the one that deals specifically with the scientific collection and analysis of physical evidence, especially of traces and material remains found during the inspection of the crime scene [5].

In recent decades, however, a tendency of some kind of approximation, interplay, unification of the content and convergence (even if not with identical forms of expression) has been observable concerning the two conceptions: the continental and common law approaches. Since the 1960s there have been and still are an increasing number of volumes published under the title "criminalistics", drawing nearer to the continental designation [6].

One example for this is the Lab Manual volume published in the United States in 2001. Its sub-title ("An introduction to forensic science") refers to forensic science, at the same time the main title is "Criminalistics" [7]. 
As for its content, it provides a detailed analysis of the meticulous methodology relating to the examination of physical evidence based on natural scientific knowledge. A similar conception may be found in the works of several authors, let us mention as an example the case of O'HARA. In two of his basic works, he deals with "Criminalistics" having the nature of criminal techniques and "Criminal investigation" having the nature of crime-solving tactics [8].

In the 2000s, especially in American summary works one may - repeatedly - increasingly encounter the expression "criminal investigation" which is also drawing nearer to the continental use of the terminology. As for its content, nowadays it covers mainly the continental crime-solving tactics and crime-solving methodology [9].

More specifically, it comprises methods of crime scene investigation, line-up or one on one confrontation (USA), or identity parade (England), the interrogation (USA) or questioning (England) of suspects and witness interviews. This category may also include data collection from informants, analyses and other sources (e.g. records, surveillance), the planning, organization, logistics and "management" of investigation, modes of search, body-search, seizure, the tactics of arrest, custody, detention, pre-charge detention, preliminary detention, the interpretation of rules of evidence, as well as tactical recommendations, professional "tricks of the trade" applicable to the individual crimes and groups of crime.

Thus, on the whole, the review of content elements leads one to the conclusion that, basically, both approaches divide the field of science designated as criminalistics by us and on the Continent into identical areas. In other words, criminalistics is divided into crime-solving techniques, constituting the forensic part - "forensic science" or "sciences" in the plural with reference to the underlying natural sciences -, and crime-solving tactics based mainly on social scientific knowledge, which is embedded in "criminal investigation" and "criminal psychology" in common law academic literature. Crime-solving methodology focusing on individual crimes is also included in "criminal investigation".

In addition to the above it must be noted that out of the continental countries in France (in Belgium GODDEFROY, LOUWAGE, LECHAT, in Italy OTTOLENGHI, ALTAVILLA) apart from "la criminalistique" (CECCALDI, CHEVET-MARAND, BUQUET), or criminalistics, the knowledge termed as "police scientifique" (ROBINSON, SANNIE, RIBERIO) or scientific police, "police judiciaire" (HREBLAY) or judicial police science, or pursuant to LOCARD's "Manuel de technique policiere" (LE CLERE), police technique has also been linked to the cultivation of some areas of criminal investigation. Today one encounters the term "criminalistics" again. (CECCALDI, CHEVET-MARAND, FOMBONNE, LOCARD) The university textbook published in Paris in 2001 already bore the main title "Manuel de criminalistique moderne" (Manual of modern criminalistics) and the sub-title "La science et la recherce de la preuve" (The science and research of evidence) [10].

In Europe in German-speaking countries (e. g. SCHNEICKERT, GROSS-SEELIG, KLEINSCHMIDT, WIETCZOREK, GEERDS, KUBE-STÖRZER-TIMM, BRODAG, CLAGES) and to the east of them, the term "criminalistics" was customary almost everywhere in the past and this is the accepted terminology today as well. (E. g. ALAMOREANU, BELKIN-WINBERG, BÍRÓ, BÓCZ, FILIPPOV, GARAMVÖLGYI, KERTÉSZ, KOBOVAC, KRAJNIK, KRIVOKAPIC, LATIFI, HOLYST, HOROSZOWSKI, MALEVSKI, MAVER, METENKO, MIRCEA, MUSIL, PAPES, PAVISIC-MODLY, POPA, PORADA, SIMONOVIC, STANCU, TREMMEL-FENYVESIHERKE, VODINELIC-ALEKSIC, ZAMFIRESCU-POPESCU).

At the same time, one may also observe changes in the continental conception, more specifically, phenomena, the adoption and application of terms pointing in the direction of forensics. It is being infiltrated through the cultivation and terminology of the subfields applied in the common law system. As an example of approximation and convergence between the two systems one may mention that the interpretation of evidence, the "show up" model plays an increasing role in the continental approach as well [11].

It may also be perceived concerning both schools of thought that the underlying basic scientific knowledge is derived from (forensic) biology, chemistry, physics, anthropology, pathology, serology, toxicology, but there are also close links with knowledge in the fields of applied ballistics 
and photographic technology. In recent decades this circle has been extended to cover, as new fields, molecular genetics, information technology (computer forensic technology, cyber forensics, digital forensics, digital investigation, web-analysis), including for example the computerized analysis of human voice and voice carriers (computer-voice analysis), identification of computer writing and computer printers (printer-identification), forensic archaeology, forensic dentistry, modern forensic entomology dealing with insects, modern forensic geology, DNA profiling (DNA analysis), forensic botany and zoology.

As a special technical method one may also mention the analysis of evidence (crime analysis), operating with the help of crime mapping and geographic profiling, the application of the mathematics-based Bayes' Theorem in the context of identification analyses, the theory of document analysis (hand- and machine-written documents), images analysis, and analyses for the identification of ridges and edges in skin patterns ("ridgeology" - "edgeology") [12].

Within the range of tactics, one may highlight the knowledge areas of forensic administration-management and logistics, forensic nursing, security management and personality profiling (profile-analysis-). As new - a few decades old or even younger - fields in the methodology of individual crimes one may regard, for example, the investigation of accidents caused by design or construction (engineering failures), cases of fire (fire science) and explosions (bombs, explosives and residues).

In summary, it may be concluded that although there are notional differences between the continental and common law conceptions of the science of criminal investigation, their subject-matter and objectives are identical, and their contents are in accordance with each other. As a tendency it may be established that one may witness the gradual demolition of the rigid boundaries between these conceptions, and the present is already characterized by their mutual interaction.

\section{2. The system of criminalistics}

In accordance with the continental conception, criminalistics may be divided into three parts also in Hungary: a general part consisting of crime-solving techniques and tactics, and crime-solving methodology, which may be regarded as a special part. Apart from the above, the history and theory of criminalistics and crime-solving strategy are also classified under the general part by academic literature, and in my opinion, crime-solving logistics also belongs here now [13].

Out of crime-solving techniques and tactics, playing a significant role in the dissertation, crime-solving techniques serve the purpose of the expedient and professional utilization of natural scientific and technical-technological means and methods in the field of the detection and prevention of crime [14].

These means and methods may include any results, achieved in other fields and subfields of science that may be used effectively by crime-solving techniques without any change, e.g. physical, chemical instruments, measuring procedures, optical and computer devices, or that may be utilized in criminal investigation following their further development precisely by crime-solving techniques, for example, forensic photography, voice identification, serological analyses. Finally, there are special subfields and disciplines of significance that have been established, elaborated and provided with firm foundations by crime-solving techniques. Such are, for example, criminal traceology, the keeping of records and personal identification based on a system of fingerprints, dactiloscopy, forensic computer analysis of writing and documents, criminal ballistics or (special) scent identification (by sniffer dogs) $[15,16]$.

In comparison, criminal tactics concentrates not on information carriers of a physical nature, but rather on the main characteristics and interconnections of the phases of obtaining evidence of a personal nature, connected with defendants, victims and witnesses. It contributes to the effective and efficient execution of investigatory acts also by pointing out sources of danger concerning the origin and obtaining of individual types of evidence and potential shortcomings in the conduct of the body or person carrying out the investigation. On the other hand, with the assistance of forensic computer technology and behavioural science, crime-solving tactics endeavours to harmonize, as required, the requirements relating to the planning, organization, integration and logistics of overt and covert investigation and operations connected with data acquisition and processing. 
Crime-solving methodology is traditionally regarded as the third part of criminalistics. In the Anglo-Saxon model, both in England, her environment and the United States, analyses and guides relating to individual offences appear under the headword "criminal investigation". Crime-solving methodology does not deal with the efficient investigation of crime in general, but instead - linking and adapting, as far as possible, basic knowledge derived from crime-solving techniques and tactics - it concentrates directly and specifically on the exploration and proof of individual categories of crime and tactical recommendations relating to them (for example, relating to the investigation of homicide, arson, explosions, burglary.) Basically, crime-solving methodology may also be considered a specialized area of criminalistics which focuses on the typical ways of perpetration of a given type of criminal offence, the potential physical and personal sources of information relating to it and the characteristics of the criminal case in general; it specifies, supplements and modifies general criminal technical and tactical information and tasks as required and links them with different points of emphasis and criteria.

With respect to all of the above, it seems right to divide criminalistics into a general and a special part. The first one includes - apart from crime-solving techniques and tactics, theory and logistics - also crime-solving strategy, which focuses mainly on objectives defined by crime-solving politics, being of a criminological nature. It endeavours to outline a series of comprehensive national, regional or municipal-local measures, which serve both the purpose of crime detection (reactive measures) and that of crime prevention (proactive measures).

As opposed to all this, methodology as the special part - both in Continental Europe and in the Anglo-Saxon territories - comprises the most important and most peculiar technical and tactical potentials, problems, difficulties, troubles and erring factors relating to detection essentially only with regard to individual types of crime.

\section{3. Contacts of criminalistics with other disciplines}

Criminalistics, as an empirical science of fact, has a wide-ranging system of contacts. Based on my classification, three main groups may be distinguished.

1. The first group is that of sciences having the closest contacts with criminalistics, which comprises criminal sciences dealing primarily with criminal activity, criminal offences and perpetrators of crime. They include:

a) criminal law (normative);

b) criminal procedural law (normative);

c) criminology (as a factual science);

d) victimology (becoming more and more independent, also as a factual science);

e) law of penal enforcement (penology as a normative science);

f) forensic psychology (as a special branch of psychology);

g) forensic medicine (including anthropology).

2. The second significant group of contacts of criminalistics is made up of technical and natural sciences as "cross-section" sciences, including - in my view - in particular:
a) biology;
b) chemistry;
c) physics;
g) cybernetics;
a) philosophy;
b) psychology;
c) logics;
d) sociology;

d) technical (engineering) sciences;

e) mathematics (mathematical logics);

f) information science (information theory);

h) "bridge or ferry sciences" [17].

3. The third large group of sciences having contacts with criminalistics is made up of the following branches of "intellectual scientific" (GEERDS) social sciences in particular: 
e) pedagogy;

f) statistics;

g) archaeology;

h) science of policing.

From the examination of the contacts of criminalistics one may draw the conclusion that from the beginning, the fast development of modern criminalistics was due to the fact that it was increasingly able to adapt to the challenges, posed by large-scale criminal activity in major cities, caused by urbanization, and it did so within the frames of an interdisciplinary (and at the same time, mutual) transfer of knowledge. This development was assisted by the transplantation of knowledge relating to discoveries and inventions, unearthed by medicine (toxicology) at first, then by various other social and natural sciences, as well as through the utilization and sensible adoption of the research results. Meanwhile, criminalistics itself, with its theoretical and practical experts and organizations working professionally and competently as a single group - relying on the results of information science - established and elaborated autonomous branches of knowledge and methodologies, having a special regard to the increased demands as well as technical, scientific possibilities. (As an example for this, see traceology, dactiloscopy, ballistics, writing analysis, profiling, polygraph testing or covert means.)

It may be added in summary of the above contacts that criminalistics can be characterized not only as a continuously expanding treasury of indirect evidence, obtained and analysed based mainly on natural scientific knowledge, but also as the involvement, integration and transplantation of the most diverse professional knowledge and, in general, of branches of science into the detection of crime. Making use of this diverse special expert knowledge requires above all the employment of experts and consultants. Having regard to this interconnection, it may also be stated that the more knowledge one has of interdisciplinary criminalistics, the more special fields and experts he/she can make use of in order to detect crime and so he/she will have a more effective, or more diversified and thorough information base, and he/she will collect data and obtain evidence more effectively. In my view, all this, in turn, is always focussed on identification.

\section{4. Milestones in the history of criminalistics}

Since criminalistics is a universal discipline, it is worth having a glance at and examining in a (world) historical perspective through what stages one has arrived at the techniques, tactics and methods, applied today. Reviewing the past in the spirit of this idea has been useful for my research, because this review has become an organic, preparatory phase in the analysis of the present tendencies of criminalistics.

The historical development of criminalistics is dealt with extensively in world academic literature. In my dissertation I presented important historical data, derived rather from sources that had so far been treated to a lesser extent in Hungary. On the other hand, I tried to highlight milestones and the persons, connected with them in an attempt to clarify the starting points and main forces behind the development of modern criminalistics and so as to understand the present events and developments better through the past and, at the same time, to be able to form a more accurate conception for the future, based on which I could model the possible development and which would back up my intuitions and suggestions.

Based on my approach, the past of criminalistics may be divided in two major stages. The watershed is the middle of the $19^{\text {th }}$ century. 1838 saw the publication of a volume by Ludwig Hugo Franz von JAGEMANN (1805-1853) entitled "Handbuch der gerichtlichen Untersuchungskunde" ("Manual of the Science of Criminal Investigation"). The date or timing of the publication is not accidental. It is from this time on that, as a consequence of the development in natural sciences, one has been able to insert the expression "modern" and omit the attribute "traditional" before the word criminalistics. By this I would like to refer to the fact that prior to that time in the history of mankind one cannot really speak of human activity, directed at the fair and authentic revelation of facts relying on (natural) scientific knowledge. It was in the $19^{\text {th }}$ century that it was finally declared as a principle that the emphasized role of confessions as the queen of evidence could no longer be 
maintained. This is explained by the fact that confessions implied forcible interrogation or torture with thousands of horrible varieties - which used to be a legally approved and regularly applied tool in the hands of "fact finders" from ancient times right until the end of the feudal age. As a result of the work of the greatest thinkers of the Enlightenment, the French MONTESQUIEU, VOLTAIRE, DESCARTES, DIDEROT, the Italian BECCARIA, the German THOMASIUS, reforms in criminal law, including procedural law, swept through the whole of Europe. Parallel to the abolition of torture (ordeals and trials), forced confessions of defendants were also pushed to the background, instead the principle of the free evaluation of evidence was introduced, in which witness statements no longer played a dominant role, because their truth content became also questioned; as cultivators of science started to recognize possibilities of error already at that time. All this served as a starting point and basic precondition for authorities to search for other evidence than personal statements made by the person under prosecution or the witness; in other words, this led to the fact that traces and material remains, physical evidence, based on special natural scientific knowledge and factual experience - as "objective witnesses" - came into the limelight. It is their impartial analysis by experts that provides the answers to the fundamental, relevant questions relating to the facts of criminal cases - proceeding from the bare suspicion, intuition and version to certainty. Consequently, the history of criminalistics is also the history of - the beginning, expansion and increasing accomplishment of - the continuous, still ongoing development of indirect evidence.

After all this it is obvious why one may consider epoch-making JAGEMANN's work of 1838 and GROSS's work ("Handbuch für Untersuchungsrichter als System der Kriminalistik") of 1893 - the latter author being regarded as the "father" of criminalistics. They really marked the beginning of a new era, which was triggered off by two changes. On the one hand, in the field of social sciences the intellectual movement of the Enlightenment established the conceptual system of the rights of the accused as forming part of human rights. Codes of criminal law and criminal procedure were born one after the other, supplying the underlying principle and legal frames for the fair exploration of facts and for a genuine demand to reveal the truth. On the other hand, the revolutionary, sudden development of natural sciences created the theoretical and practical possibility for rendering the past, cognizable in such a way so as to shift the emphasis from confessions, classified as personal evidence to "incorruptible" or "silent witnesses", physical evidence, traces and material remains [18].

The healthy, one might say, well-timed co-development of the two basic pillars, social and natural sciences - especially biology, chemistry, physics - served as a basis for the evolution of the new fact-finding methodology. It flows from this very origin that criminalistics is - partly - considered an applied science, since both its evolution and later development are closely connected with the results of the underlying basic sciences. Criminalistics develops and steps forward day by day by applying those results to the detection of crime, and this is a process that has been going on for around one and a half centuries. When one speaks of criminalistics in a modern sense, in any case, it may be regarded a young branch of science.

In order that one could speak of criminalistics, as a matter of course, the basic social and scientific conditions for this had to be established even in the states said to be developed at that time. The first and second of those conditions were:

a) the nationalization of criminal investigation and, at the same time, the elimination of the hegemony - but not of the existence - of criminal investigation of a private nature;

b) achieving a certain level of development of natural sciences.

Ad a) Within the range of criminal investigation activity:

- the State undertakes to give a repressive official response to criminal offences, provides a service within the frames of performing this obligation, it forbids criminal behaviour and takes action against the offender;

- the State provides protection to its citizens and assumes responsibility for their security.

Ad b) The development of natural sciences as the second condition can also be dated to the $19^{\text {th }}$ century in Europe, therefore, Europe, more specifically its continental part with a Prussian-French axis, may be considered as the "cradle", place of birth of modern criminalistics. It was here that the anomaly of the inquisitorial model and uncertainties relating to personal evidence and 
interrogations were first recognized and pointed out. It was here and at this time that the demand for social cognizance, or one might say, the unappeasable intellectual desire to give priority to physical evidence first arose. The authentic cognition of the past first acquired significance in the economy, then in public safety and investigation.

It is not by accident that the milestones of the historical route of modern criminalistics are basically linked to the old continent. In my view, the five milestones are:

1) personal identification based on finger-marks and finger-prints (starting from 1900-1910) (BERTILLON, COULIER, HERSCHEL, FAULDS, HENRY, HERSCHEL, GALTON, VUCETICH) (+other traces - BALTHAZARD, GODDARD, GROSS);

2) identification of blood (1920s-30s) (including the analysis of other material remains) (LOCARD and GETTLER, GONZALES, NICEFORO, NORRIS, OTTOLENGHI, POPP, REISS, SÖDERMANN) [19];

3) identification by neutron activation analysis (from the 1930s-40s) (JERVIS, GUINN, PERKONS);

4) identification based on DNA (WATSON-KRICK - from 1953, JEFFREYS - from 1986) [20];

5) digital data serving the purpose of establishing the facts of a case - from the 1990s (CASEY, MARSHALL) [21, 22].

In this context I would like to emphasize that, in my view, DNA profiling does not simply constitute the fourth milestone, but it also plays a pioneering role as second generation evidence requiring a different type of expert, instrument, method and approach. DNA profiling, in conjunction with the fifth milestone of digital data - as a change in paradigm - constitutes new generation evidence as opposed to the customary, classical, traditional first generation analysis of traces (including finger-marks, foot-marks, marks of footwear, tool marks, marks of weapons and tracks left by vehicles), material remains (blood serology, hair, textile threads, fibres, poisons, paper, glass etc.), handwriting and type-writing.

The detailed analysis of the above milestones in the dissertation shows that "craftsmen's" criminalistics characterizing the $19^{\text {th }}$ century came to an end in the $20^{\text {th }}$ century. On the other hand, in the $21^{\text {st }}$ century MORRIS has rightly stated that detective work as "artisan craft" is a thing of the past, but the professional objectives of the investigator have not changed and they may be achieved only through the life-long and continuous development and learning [23].

\section{5. The basic principles of criminalistics}

Concerning the contacts of criminalistics, I analysed its relationship with other branches of law, including for example its interaction with the law of criminal procedure, having the closest link with it, and its relationship with criminal law, which formulates facts that are of relevance from the aspect of criminal law. Both branches of law have basic principles that have been elaborated for several hundred years, which serve as guidelines and usually, right at the beginning of the codes, provide guidance and indicate with exclamation marks the "paths" to be followed by the appliers of law. One must not deviate from them during the entire course of action and they illuminate the right way as lanterns. As criminalistics is not a science of law, but that of facts, it has no summary code either. The representatives of the science hardly ever formulate principles, carved in stone at the beginning of monographs or textbooks on criminalistics - forensic sciences. At the level of generalities, one may most frequently come across the notions of lawfulness and speed, while in some places one may read about the requirements of completeness, flexibility, purposefulness, professionalism, control as well, and in the case of covert means expedience, proportionality and subsidiarity also occur. In my view, it is possible to formulate other special principles as well in addition to the above which, as basic principles, may provide more specific support to those, who explore past facts for the sake of accurate and undistorted detection. However self-evident these principles may seem, they do great service by enabling us to see more clearly.

Logically, the six lines of basic principles are built up so that the main questions relating to the detection of the facts of the case are always to be clarified first: 
1. Seven main criminalistical questions (the main list of questions) in order to get to know and reconstruct the past.

2. The past is cognizable, namely, with the help of traces and material remains.

3. Every crime leaves a trace. These traces are to be collected systematically just like personal evidence [19].

4. Each criminalist is worth as much as many data he/she has, on the other hand, the mine of data is constituted by the scene and the primary measures, linked to it [24].

5. The importance of the first strike(s), from which one may recover and obtain the necessary data, required for the ultimate aim, identification [25].

6. Natura non facit saltum. Nature does not repeat itself. It renders possible the individual identification of persons [26].

In the context of the six enumerated principles, concerning the fourth "each criminalist is worth as much as many data he/she has" I set out in detail the types of scenes and records, their roles, the significance and accessibility modes of data, obtainable by raster investigation, covert forces-ways-means, the "first strike" - "erster Angriff" - and measures, taken on hot trail [27].

\section{6. Present world tendencies of criminalistics}

By pointing out the milestones of modern criminalistics, dating back one and a half centuries I consider - I also presented the tendencies in the development of the science and also changes in the paradigm and generations of evidence. By the following enumeration I would like to outline the most characteristic features of criminalistics in the present age - the beginning of the $21^{\text {st }}$ century.

In this study I am pointing out and presenting (not in detail) the following major current world tendencies in criminalistics.

a) The primacy of crime-solving techniques;

b) Specialization;

c) Minutization (microscopization, miniaturization);

d) The past drawing closer - the sharpening of pictures;

e) Expertization;

f) Increase in the level of probability;

g) Dominance of team-work;

h) Computerization;

i) Cyber intelligence (pushing forward of the "digital commando");

j) Increased value of covert means and methods;

k) Internationalization;

1) Multiplication of situations of danger;

m) Privatization.

The enumeration of tendencies is not exhaustive, but the listed tendencies, in any case, comprise basic guidelines for the second decade of our century. Between them one may discover numerous interconnections. First of all, their major part is based on the technical breakthrough as a starting point, while there is also interaction between them. Let us just mention the computer as an achievement that provides a possibility for the primacy of technology, quality specialization and a sharper view of the past. It also appears in the rising level of expertization, probability and digital data collection, in the development of overt and covert means, cyber-investigation and international cooperation, and it is significantly present in the work of the private sector as well [28-30].

Besides the intertwining and close interaction between these tendencies, one may also perceive that they point in the same direction and their progress has the same focus: to create a more secure world by increasing the quantity and mainly the quality of means for the prevention and detection of crime.

\section{Possible development of criminalistics in the near future}

Following the examination of tendencies, I attempt to outline the future theoretical and practical possibilities of the development and improvement of criminalistics, the expected further tendencies. On the one hand, I have defined the scientific fields where a real and at the same time 
conscious development of present criminalistical methods would be expected and required, on the other hand, I have formulated our intuitions and also our recommendations concerning development and the expected challenges facing criminalistics.

In this context I list (draftly) the following:

a) the exploration of human smell, the possibility of discovering its molecular structure and the scientific values connected with it;

b) the creation - instead of the polygraph as a tool for detecting and orienting the detection of lying-telling the truth - of a "monoscanner" or "mind-reading" device, its advantages from the aspect of a more efficient and reliable search for the truth;

c) means and methods for testing sincerity besides the polygraph; linguistics;

d) future possibilities, implied by the triad of graphocomparison, graphoanalysis and grapho-

e) potential - computer-based - techniques and possibilities for the identification of writing; (CEDAR, FISH, computerized graphometry, SignPass, TRIGRAPH);

f) the formation and extension of mobile on-the-scene laboratories and the future of DNA testing;

g) the future possibilities and challenges, posed by digital detection; (training of digitdetectives, ethical-"white hat" hackers, sound identification, enhancement of hot spots analysis by GIS, on-the-scene 3D scanner, development of face reconstruction based on superprojection-imposition);

h) the development of secret techniques for obtaining, collecting and mining data;

i) the requirement of the introduction of forensic nursing and of the forensic nurse in Hungary;

j) the adoption and spread of the Bayes analysis in Hungary;

k) the refining of profile-constructing techniques;

1) the introduction and more active use of cognitive and other new interviewing techniques.

\section{Conclusion}

At the end of my study I remarked that even if all my predictions, prognoses, intuitions and recommendations found a berth, even if technology, digitalization, computers, natural and social sciences all joined forces, it would still not be possible to replace and substitute for the real pledge of the success of future criminalistics, the criminalist himself/herself. He/She constitutes the other focus besides identification. The specialist, explorer, data collector, the efficient law enforcer, who undertakes risks and dangers, faces continual challenges, the "great fighter" on the real and virtual battlefields that seem unremittingly infinite, where he/she has really only one weapon in his/her hands: criminalistics as an "international treasure" [31].

\section{References}

[1] Mommsen, T. (1899). Römisches Strafrecht. Berlin: Dunckler u. Humblot Verlag.

[2] Belkin, R. S., Winberg, A. I. (1969). Kriminalistika i dokazivanie. Moscow, 215.

[3] Osterburg, W. J., Ward, H. R. (2010). Criminal Investigation: A method for Reconstructing the Past. New Providence: Lexis Nexis, Anderson Publishing, 720.

[4] O’Brien, K. P., Sullivan, R. C. (1976). Criminalistics. Theory and practice. Holbrook Press.

[5] Kirk, P. (1953, 1974). Crime Investigation. Interscience Publications. New York-London-Sydney, Chichester: Wiley, 784.

[6] O’Hara, C., Osterburg, J. W. (1960). An Introduction to Criminalistics. New York.

[7] Saferstein, R. (1982). Forensic Science Handbook. Englewood: Princehall, 725.

[8] O’Hara, C., O’Hara G. (1994). Fundamentals of Criminal Investigation. Springfield, 991.

[9] Swanson, Ch. R., Chamelin, N. C., Territo, L. (1981). Criminal Investigation. New York: Random House, 24.

[10] Buquet, A. (2001). La science et la recherche de la prevue. Paris: Presses Universitaires de France. 
[11] Metenko, J. (2012). Kriminalisticka taktika. Bratislava: Akadémia Policajného Zboru v Bratislave, 126.

[12] Rossmo, D. K. (2000). Geographic Profiling. Boca Raton: CRC Press.

[13] Katona, G. (2002). The criminalistics and the criminal sciences. Budapest: BM Kiadó.

[14] Kertész, I. (2000). (Unfinished war). Budapest: BM Kiadó.

[15] Hautzinger, Z. (2003). Criminalistical identification of human scent. Fenyvesi Csaba-Herke Csongor (szerk). Emlékkönyv Vargha László egyetemi tanár születésének 90. évfordulójára. Pécs, 79-89.

[16] Horváth, O. (2018). Criminalistical application of searching and identificating dogs. Pécs.

[17] Katona, G. (2002). The criminalistics and the criminal sciences. Budapest: BM Kiadó.

[18] Houck, M. M., Siegel, J. A. (2006). Fundamentals of Forensic Science. Amsterdam-Boston-Heidelberg-London-New York-Oxford-Paris-San Diego-San Fransisco-Singapore-Sydney-Tokyo: Elsevier, 907.

[19] Locard, E. (1931-1940). Traité de criminalistique I-VI. Lyon: Desvigne.

[20] Jeffreys, A. J., Wilson, V., Thein, S. L. (1985). Individual-specific "fingerprints" of human DNA. Nature, 316 (6023), 76-79. doi: http://doi.org/10.1038/316076a0

[21] Casey, E. (Ed.) (2000). Digital Evidence and Computer Crime: Forensic Science, Computers and the Internet. New York: Academic Press.

[22] Mészáros, B. (2011). Covered investigation. Pécs, 2011.

[23] Morris, B., Willamson, T., Wright, T., Newburn, A. (2008). History of criminal investigation. Handbook of Criminal Investigation. London, Canada: Willan Publishing, 2008.

[24] Orbán, J. (2018). Bayes-nets in criminal cases. Pécs.

[25] Petrétei, D. (2018). Crime scene in aspect of standardisationing tendencies and new Criminal Procedure act. Rendőrségi Tanulmányok, 3.

[26] Angyal, M. (2014). Identification of unknoun dead bodies. Pécs, 2014.

[27] Forker, A., Bertram, M., Gläser, H., Leonhardt, R. (1972). Über das Wesen und einige Grundsätze des ,ersten Angriffs”. Forum, 9, 404-407.

[28] Geerds, F. (1983). Entwicklungsstand und Tendenzen der wissenschaftlichen Kriminalistik in der Bundesrepublik Deutschland. Wiesbaden.

[29] Grafl, Ch. (2002). Perspektiven der Kriminalistik. Kriminalistik, 6, 379-394.

[30] Fejes, I. (2009). Tendencies of Criminalistics Development in the 21th Century. NBP Journal of Criminalistics and Law, 95-107.

[31] Ubelaker, D. H. (2011). The Forensic Sciences: International Perspectives, Global Vision. Journal of Forensic Sciences, 56 (5), 1091-1093. doi: http://doi.org/10.1111/j.1556-4029.2011.01876.x 